\title{
The relation of chronic idiopathic urticaria with fibromyalgia, sleep disturbance and anxiety
}

\section{Kronik idiopatik ürtiker ile fibromyalji, uyku bozukluğu ve anksiyete ilişkisi}

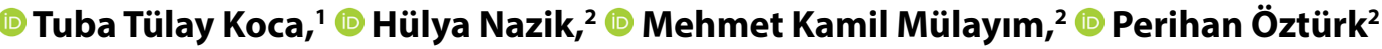 \\ 'Department of Physical Medicine and Rehabilitation, Sütçü İmam University Faculty of Medicine, Kahramanmaraş, Turkey \\ ${ }^{2}$ Department of Dermatology, Sütçü İmam University Faculty of Medicine, Kahramanmaraş, Turkey
}

\begin{abstract}
Introduction: Fibromyalgia syndrome (FMS) and chronic idiopathic urticaria (CIU) are closely related due to peripheral neurogenic inflammation (neuropeptide secretion), immune dysfunction, and somatic complaints such as fatigue, pain, anxiety, and sleep disturbance. This study aimed to reveal the relationship of CIU with FMS, sleep disturbance and anxiety.

Methods: A total of 51 patients with CIU aged 18-64 years (36.2 \pm 10.4$)$ and 45 sex- and age-matched healthy controls were included. Urticaria activity score (UAS) was assessed for the severity of urticaria. The 2010 American College of Rheumatology classification criteria were used for FMS diagnosis. The participants were evaluated with visual analog scale (VAS), fibromyalgia impact questionnaire (FIQ), Pittsburgh sleep quality index (PSQI), and Beck anxiety inventory (BAI).

Results: The presence of FMS and body mass index (BMI) were significantly higher in the urticaria group compared with the control group. The mean FIQ and UAS of the urticaria group were $47.0 \pm 22.1$ and $1.3 \pm 0.9$, respectively. UAS was positively correlated with FIQ, PSQI, BAl and VAS $(r h o=0.411 p=0.004 ; r h o=0.310 p=0.034 ; r h o=0.419$ $\mathrm{p}=0.004$; rho $=0.414 \mathrm{p}=0.004$; respectively). The presence of FMS was found to be significantly associated with high BMI $(p=0.04)$.

Discussion and Conclusion: The prevalence of FMS was higher in patients with CIU than control group. Also, FMS was more severe, general pain and fatigue, sleep disturbance and anxiety were higher in patients with high urticarial activity.
\end{abstract}

Keywords: Anxiety disorder; fibromyalgia syndrome; sleep disturbance; urticaria.

$\mathrm{U}$ ticaria is a cutaneous reaction of the skin that is welldefined, localized, erythematous, and characterized by a sudden itchy rash lasting several hours. Chronic idiopathic
Özet

Amaç: Fibromiyalji sendromu (FMS) ve kronik idiyopatik ürtiker (CIU), periferik nörojenik inflamasyon (nöropeptid salınımı), immün işlev bozukluğu ve yaygın halsizlik, ağrı, anksiyete ve uyku bozukluğu gibi somatik şikayet nedeniyle yakından ilişkilidir. Bu çalışmada CIU ile FMS, uyku bozukluğu ve anksiyete ilişkisini ortaya koymak amaçlandı.

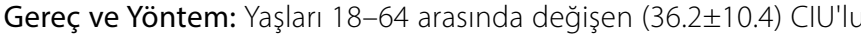
51 hasta ile cinsiyet ve yaşa uygun 45 sağılıkı kontrol alındı. Ürtiker aktivite skoru (UAS) ürtiker şiddeti açısından değerlendirildi. FMS tanısı için 2010 Amerikan Romatoloji Cemiyeti sınıflandırma kriterleri kullanılmışıı. Katııımcılar görsel analog skala (VAS), fibromiyalji etkisi anketi (FIQ), Pittsburgh uyku kalitesi indeksi (PSQI) ve Beck anksiyete envanteri (BAI) ile değerlendirildi.

Bulgular: Ürtiker grubunda FMS ve vücut kütle indeksi (VKI) kontrol grubuna göre anlamlı derecede yüksekti. Ürtiker grubunun FIQ ve UAS ortalaması sırasıyla $47.0 \pm 22.1$ ve $1.3 \pm 0.9$ idi. UAS ile FIQ, PSQI, BAI ve VAS pozitif korele idi $(r h o=0.411 p=0.004 ;$ rho $=0.310 p=0.034$ rho $=0.419 p=0.004 ;$ rho $=0.414 p=0.004 ;$ sırasılya). FMS varlığı VKi ile anlamlı ilişkiliydi $(p=0.04)$.

Sonuç: FMS prevalansı kontrol grubuna göre CIU olan hastalarda daha yüksekti. Ayrıca, yüksek ürtikeryel aktivite gösteren kişilerde FMS daha şiddetli, genel ağrı ve yorgunluk, uyku bozukluğu ve anksiyete daha yüksek idi.

Anahtar Sözcükler: Anksiyete bozukluğu; fibromyalji sendromu; uyku bozukluğu; ürtiker.

urticaria (CIU) is defined as urticaria with recurrent episodes lasting longer than 6 weeks. CIU is provoked by exercise, heat, and emotional stress. Although the underlying pathophysio-

Corresponding (IIletişim): Tuba Tülay Koca, Sütçü İmam Üniversitesi Tıp Fakültesi, Fiziksel Tıp ve Rehabilitasyon Anabilim Dalı,

Kahramanmaraş, Turkey

E-mail (E-posta): tuba_baglan@yahoo.com

Received (Geliş Tarihi): 22.01.2019 Accepted (Kabul Tarihi): 07.02.2019 
logical reasons for CIU are not fully understood, available evidence (increase in neuropeptides) indicates that peripheral cutaneous nerves can be involved. ${ }^{[1]}$

Fibromyalgia syndrome (FMS) is a chronic pain syndrome characterized by widespread pain and somatic symptoms in $2 \%-4 \%$ of the population. Pain, allodynia, and hyperalgesia are common. Fatigue, cognitive dysfunction, nonrestorative sleep, depression, and anxiety are accompanied by other somatic symptoms. The pathophysiology of FMS has not been elucidated yet, and no treatment is available for relieving all of the symptoms. Multiple factors such as genetic factors, substance $P$ and serotonin pathways, central sensitization, autonomous disfunction, hypothalamic-pituitary-adrenal axis disfunction, metabolic dysfunction, oxidative stress were found to be related to FMS pathophysiology. Currently, it is classified among central sensitization syndromes. ${ }^{[2,3]}$

Chronic idiopathic urticaria and FMS are related in many aspects. In both diseases, changes in peripheral cutaneous nerve fibers and immunological problems and dysfunctions occur. Depression, anxiety, and sleep disorders are also frequently associated with both diseases. ${ }^{[1-4]}$

There are a few literature researches related the relationship between these two diseases.

It is unclear whether the relationship between these two diseases is a coexistence or cause. This study aimed to reveal the relationship of CIU with FMS, sleep disturbance and anxiety.

\section{Materials and Method}

The study designed as case-control. A total of 51 patients with CIU, mean $36.2 \pm 10.4$ years and 45 age $(p=0.38)$ sex-matched $(p=0.27)$ healthy controls were included in the study. Urticaria activity score (UAS) was used for the severity of urticaria. ${ }^{[5]}$ To measure UAS, all patients with CIU were questioned to determine the number urticarial plaques that occurred within the last week ( $0=$ none, $1=$ mild ( $\leq 20$ plaques/24-hour), $2=$ moderate (21-50 plaques/24-hour), and $3=$ severe $(>50$ plaques/24hour), and severity of pruritus ( $0=$ none, $1=$ mild, $2=$ moderate, and $3=$ severe). Data about body mass index (BMI), duration of disease, daily antihistamine use (for the last 1 week), and a history of angioedema in patients with CIU were recorded.

All patients with CIU and controls were also questioned for symptoms and signs related with FMS. The 2010 American College of Rheumatology classification criteria were used for FMS diagnosis. ${ }^{[5]}$ The severity of FMS in study group, was assessed by using the Fibromyalgia Impact Questionnaire (FIQ), which contains 10 self-administered instruments covering physical functioning, work status, depression, anxiety, sleep, pain, stiffness, fatigue, and well-being. A visual analog scale (VAS: from $0=$ no pain to $10=$ the worst pain) was used to assess general pain and fatigue. All participants were evaluated with Pittsburgh sleep quality index (PSQI) ${ }^{[7,8]}$ and Beck anxiety inventory (BAI).

Chronic urticaria is now divided into chronic spontaneous ur- ticaria and chronic inducible urticaria. There are inflammatory conditions which may lead to urticarial rashes, but those are not usually considered as urticaria. The basic investigations suggested by GALEN/WAO guidelines include erythrocytes sedimentation rate (ESR) and complete blood count to rule out inflammatory conditions. ${ }^{[5]}$ Patients with chronic inflammatory disease, malignancy, infection, pregnancy and those with nonurticarial dermatological complaints were excluded from the study. Female patients were selected especially during premenopausal period. Hormone levels are known to affect both FMS and CIU.

The PSQI scale provides information about the type and severity of sleep disturbance and sleep quality in the last 1 month. Using the 19 questions answered by the patient, 7 subdimensions are evaluated, including the subjective sleep quality, sleep latency, sleep duration, routine sleep activity, sleep disorder, use of sleeping pills, and daytime dysfunction. Each item in the scale is graded from 0 (no problem at all) to 3 (severe problem). The total scores for the seven subdimensions give the total PSQI score. A total score of 5 and less indicates that the sleep quality is "good!' ${ }^{[6]}$ The Turkish validity of the scale was provided by Agargun et al. ${ }^{[8]}$

\section{Statistical analysis}

All statistical analyses were carried out by using IBM SPSS version 19 (IBM Corp., Armonk, NY, USA). Descriptive data were presented in mean \pm standard deviation (SD) or median scores according to their categories and distribution. The coherence of variables to normal contribution (normality) was analysed by Kolmogorov-Smirnov test as the number of patients in study group is more than 30 . The Spearman's correlation analysis was used to analyze the level of the correlation between the variables.

Categorical data are reported as percentages and are compared using the Chi-squared test. Continuous data are reported as mean with standard deviation or median with minimum and maximum and compared using parametric/ non-parametric tests according to their normal or anormal distribution. We also used histogram for this. A $p$ value of $<0.05$ was considered statistically significant.

\section{Results}

Fifty-one patients with urticaria, mean $36.4 \pm 10.4$ years aged were included in the study. The control group included 45 subjects of similar age $(p=0.38)$ and gender $(p=0.27)$ with no dermatological complaints. The descriptive and analytic data of the groups were shown at Table 1.

The presence of FMS $(50.9 \%, p=0.00)$ and BMI $(30.3 \pm 6.2 \mathrm{~kg} /$ $\mathrm{m}^{2}, \mathrm{p}=0.00$ ) were significantly higher in the CIU group compared with the control. The mean FIQ of the urticaria group was 47.0 \pm 22.1 (Table 1).

The most frequent UAS was level 1 with ratio of $52.9 \%$ and $66.7 \%$ had a history of urticaria that lasted longer than 1 year (Table 2). The frequency of antihistaminic use was $46.2 \%$, 
Table 1. Descriptive and analytic data of the groups

\begin{tabular}{|c|c|c|c|c|c|c|c|}
\hline Group/mean $\pm S D$ & $\begin{array}{c}\text { Age (year) } \\
\text { Gender (F/M) }\end{array}$ & $\begin{array}{c}\text { BMI } \\
*\left(\mathbf{k g} / \mathrm{m}^{2}\right)\end{array}$ & $\begin{array}{c}\text { VAS } \\
(0-10 \mathrm{~cm})\end{array}$ & $\begin{array}{l}\text { FMS } \\
\text { N/\%* }\end{array}$ & FIQ & PSQI & BAI \\
\hline CIU $n=51$ & $\begin{array}{c}36.2 \pm 10.4 \\
36 / 15\end{array}$ & $30.3 \pm 6,2$ & $3.6 \pm 3.7$ & $26 / 50.9$ & $47.0 \pm 22.1$ & $19.2 \pm 11.9$ & $17.14 \pm 14$ \\
\hline Control $n=45$ & $\begin{array}{c}32.2 \pm 15.8 \\
27 / 18\end{array}$ & $24.9 \pm 4.9$ & $3.4 \pm 3.1$ & $5 / 11.1$ & - & $17.8 \pm 8.4$ & $13 \pm 9.7$ \\
\hline$P$ & $\begin{array}{l}0.38 \\
0.27\end{array}$ & 0.00 & 0.93 & 0.00 & & 0.87 & 0.33 \\
\hline
\end{tabular}

SD: Standard deviation; CIU: Chronic idiopathic urticaria; BMI: Body mass index; FMS: Fibromyalgia syndrome; FIQ: Fibromyalgia impact questionnaire; PSQI: Pittsburgh sleep quality index; BAI: Beck anxiety inventory. ${ }^{*}$ Statistically significance, $\mathrm{p}<0.05$.

Table 2. The distribution of activity and duration of the urticaria in the study group

\begin{tabular}{lcc} 
UAS & $\mathbf{n}$ & $\%$ \\
\hline Level 0 (none) & 6 & 11.7 \\
Level 1 (mild) & 27 & 52.9 \\
Level 2 (moderate) & 10 & 19.6 \\
Level 3 (severe) & 8 & 15.6 \\
Duration & & \\
$<3$ months & 9 & 17.6 \\
3-12 months & 8 & 15.7 \\
$>12$ months & 34 & 66.7 \\
\hline
\end{tabular}

UAS: Urticaria activity score.

Table 3. Correlation analysis of UAS with FIQ, PSQI, BAI, VAS and BMI

\begin{tabular}{lcc} 
& rho & P \\
\hline UAS-FIQ* $^{*}$ & 0.411 & 0.004 \\
UAS-PSQI* $^{*}$ & 0.310 & 0.034 \\
UAS-BAI* $^{*}$ & 0.419 & 0.004 \\
UAS-VAS* & 0.414 & 0.004 \\
UAS-BMI & 0.054 & 0.717 \\
\hline
\end{tabular}

UAS: Urticaria activity score; BMI: Body mass index; FIQ: Fibromyalgia impact questionnaire; PSQI: Pittsburgh sleep quality index; BAI: Beck anxiety inventory; VAS: Visual analog scale. *Statistically significance, $\mathrm{p}<0.05$.

and a history of angioedema was $38.4 \%$. UAS was positively correlated with FIQ, PSQI, BAI and VAS ( $\mathrm{rho}=0.411 \mathrm{p}=0.004$; $r h o=0.310 p=0.034 ;$ rho $=0.419 p=0.004 ; r h o=0.414 p=0.004$; respectively) (Table 3 ). The presence of FMS was found to be significantly associated with $\mathrm{BMI}(\mathrm{p}=0.04)$. When we divide the group according to FMS presence, UAS was found higher in FMS group than control $(p=0.000)$ (Figure 1).

Additionally, the use of antihistamine had no effect on FMS, sleep disturbance, and anxiety; but VAS was significantly lower in the patients using antihistamines. No relation was found between FMS with duration of disease and age.

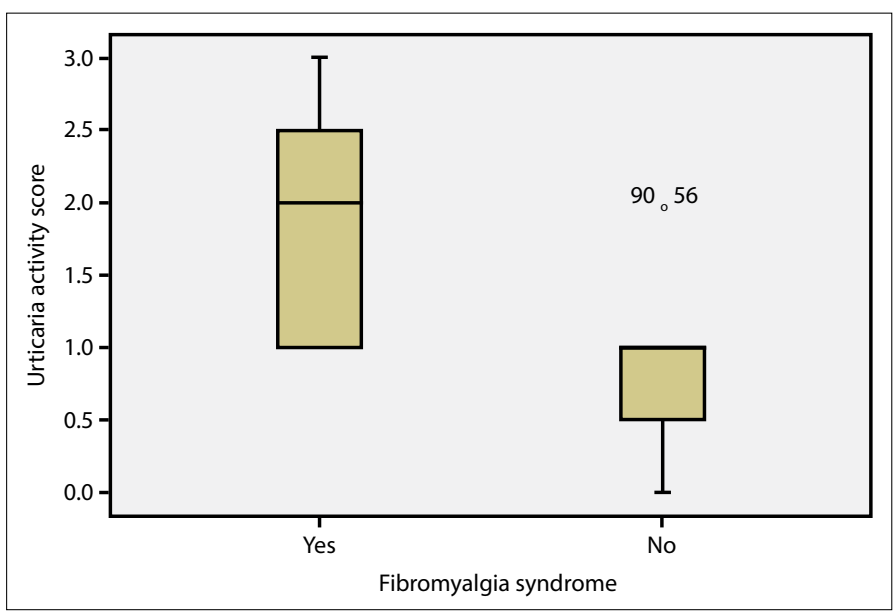

Figure 1. Boxplot of the UAS according to FMS presence.

\section{Discussion}

Urticaria is an inflammatory skin disease with transient papular skin and/or mucosal lesions characterized by subcutaneous lesions called angioedema. Acute urticaria has allergic etiology, whereas CIU is nonallergic. More than one form of urticaria can be seen in the same person. It is associated with the release of various chemicals, mainly histamine, from mast cells to the dermis layer. ${ }^{[0]}$

Despite being benign and self-limiting, CIU can have adverse effects due to chronicity and recurrence tendency. The pathophysiology of CIU is not fully understood. It is thought that some of the patients may have an autoimmune disease associated with the dysfunction of peripheral cutaneous nerves. CIU affects $20 \%$ of the population, and treatment includes avoidance of triggering factors, use of $\mathrm{H} 1$ antihistaminic drugs for rashes, and inflammation therapy, besides clinical therapy. In most patients, CIU cannot be controlled by antihistaminic therapy. In this case, immunomodulatory therapy can be applied. ${ }^{[10]}$

FMS is a chronic disease with a range of symptoms including diffuse pain, fatigue, sleep disturbance, cognitive disfunction and mood disorders (depression, anxiety). FMS is usually seen in females aged 30-50 years. Its prevalence ranges from 
$1 \%$ to $4 \%$. The patient history usually reveals a psychogenic trauma. Neural activity changes in the central nervous system, abnormal metabolism of biogenic amines, and immunologic problems may lead to the occurrence of this disease. ${ }^{[1]}$ Together with central sensitization, peripheral effects such as neurogenic inflammation also contribute to the disease. Neuroimaging methods show abnormalities in the response to neurotransmitters and pain. ${ }^{[11,12]}$ Recent evidence supports the role of cytokines, especially chemokines, in the pathogenesis of syndromes. The levels of proinflammatory cytokines, such as interleukin (IL)-1 receptor antibody, IL-6, and IL-8, were found to be high in patients with FMS. ${ }^{[12,13]}$

It is assumed that both diseases are autoimmune disorders associated with changes in peripheral cutaneous nerve fibers. The study found that the prevalence of FMS (50.9\%) was high in patients with CIU and correlated with urticaria severity and BMI. In the literature, high BMI is reported in patients with FMS. ${ }^{[11,12]}$ Moreover, FMS severity, general pain and fatigue, sleep disturbance and anxiety were positively correlated with urticaria severity. We may say that urticaria severity increases with FMS presence, depression and anxiety. Mahmut et al. ${ }^{[14]}$ found similar results on FMS prevalence in CIU patients. However, they found symptom duration longer, FIQ and VAS scores higher in the CIU group. Torresani et al. ${ }^{[15]}$ reported FMS diagnosis in $70 \%$ of patients with CIU.

CIU is a common skin disorder characterized by spontaneous recurrent well-being and itchy attacks, seriously affecting life quality. Published studies on the quality of life of patients with CIU are available. ${ }^{[16,17]}$ Wiffen et al. ${ }^{[16]}$ found a significant decrease in the quality of life of patients with CIU. The physical and psychological health was the most affected, and depression and anxiety were frequently reported in these patients. Negative correlations were also found between disease severity and quality of life in their study.

Staubach et al. ${ }^{[18]}$ found a significant decrease in the quality of life of patients with CIU, especially in social functioning and emotional areas. Psychiatric comorbidities especially in patients with chronic fatigue due to itching, swelling, sleep disturbance, and side effects of medication were also frequently observed. These patients may also have emotional disturbances, leading to troubles in expressing their emotions and defining them. ${ }^{[19]}$

Our study group mostly consisted of chronic urticaria patients with mild disease activity. We found that the severity of urticaria in patients with CIU increased with the complaints of general pain and fatigue, anxiety, and sleep disturbances. FMS negatively effects the severity of CIU. This may be caused by the exacerbation of lesions with emotional stress.

CIU may also be severe in a same patient who has severe FMS too. The relationship may be a cause or concomitance.

FMS lowers the quality of life with widespread pain, fatigue, depression, anxiety, and sleep disturbances. Recent human neuroimaging studies suggested that FMS patients exhibites altered thalamic (modulation of pain) structure and function.
${ }^{[20,21]}$ Palagini et al. ${ }^{[22]}$ hypothesized that sleep disturbances which activates stress and inflammation-related systems, plays a central role in all other symptoms. This also accounted for the high frequency of togetherness with pain, sleep and cognitive disfunctions.

FMS may lead to cutaneous nerve fiber dysfunction and release of neuropeptides, causing dermal microvessel dilation. In addition, various neuropeptides may lead to mast cell regulation, stimulating nerve endings. In FMS, skin neuropathy can cause neurogenic skin inflammation (CIU). Choi et al. ${ }^{[23]}$ and Morf et al. ${ }^{[24]}$ found diminished microcirculation in digits of FMS patients with altered capillary density and diameter.

The dysfunction in the microcirculation may play a role in the development or severity of CIU. CIU and FMS also have common clinical features due to other somatic complaints such as fatigue, pain, sleep disturbance, anxiety, and depression. Common pathophysiological pathways leading to both diseases should be investigated in order to highlighten this relationship.

\section{Limitations of the study}

Our study group mostly consisted of CIU patients who have mild urticarial activity. More than half of them use regular antihistamines which cause sleepness and dizziness similar to FMS symptoms. Both of two factors may have effected the study results.

Other limitations of the study are the non-consideration of medications used for FMS and the high BMI of the CIU group.

The inclusion of both males and females in the study is also important. FMS is a chronic disorder seen more in the female population.

\section{Conclusions}

The prevalence of FMS was found higher in patients with CIU than the control group. Additionally, FMS was more severe, general pain and fatigue, sleep disturbance and anxiety were higher in patients with high urticarial activity. Emotional stress, increase in neuropeptides, peripheral sensitization or other common pathophysiological pathways are suggested to be the possible underlying factors.

The frequency of both FMS and CIU is increasing in patients with anxiety and depression. Therefore, it is difficult to explain the relationship between these two diseases ignoring the mood disorders. Elucidating the etiopathogenesis of both diseases will guide the unidentified relationship in the future.

Conflict of interest: There are no relevant conflicts of interest to disclose.

\section{References}

1. Maurer M, Church MK, Marsland AM, Sussman G, Siebenhaar F, Vestergaard C, et al. Questions and answers in chronic urticaria: where do we stand and where do we go? J Eur Acad Dermatol 
Venereol 2016;30(5):7-15. doi: 10.1111/jdv.13695.

2. Sumpton JE, Moulin DE. Fibromyalgia. Handb Clin Neurol 2014;119:513-27. doi: 10.1016/B978-0-7020-4086-3.00033-3.

3. Koca TT, Tugan CB, Koçyiğit BF, Nacitarhan V. Fibromyalgia awareness in women aged between 18 and 75 years: a current view to fibromyalgia. J Public Health (Berl.) 2018. doi: 10.1007/s10389018-0970-0.

4. Criado PR, Criado RF, Maruta CW, Reis VM. Chronic urticaria in adults: state-of-the-art in the new millennium. An Bras Dermatol 2015;90(1):74-89. doi: 10.1590/abd1806-4841.20153509.

5. Zuberbier T, Bindslev-Jensen C, Canonica W et al: EAACI/GA2LEN/ EDF guideline: definition, classification and diagnosis of urticaria. Allergy 2006; 61:316-20

6. Wolfe F, Smythe HA, Yunus MB et al: The American College of Rheumatology 1990 Criteria for the Classification of Fibromyalgia. Report of the Multicenter Criteria Committee. Arthritis Rheum 1990;33:160-72

7. Buysse DJ, Reynolds CF, MonkTH, Berman SR, Kupfer DJ. The Pittsburgh Sleep Quality Index: a new instrument for psychiatric practice and research. Psychiatry Res 1989;28:193-213.

8. Agargun MY, Kara H, Anlar O. Pittsburgh uyku kalitesi indeksinin geçerliliği ve güvenilirliği. Turk Psik Der 1996;7:107-15.

9. Soria A, Francès C. [Urticaria: diagnosis and treatment]. Rev Med Interne 2014;35(9):586-94. doi: 10.1016/j.revmed.2014.01.008. Epub 2014 Feb 25.

10. Jafilan L, James C. Urticaria and Allergy-Mediated Conditions. Prim Care 2015;42(4):473-83. doi: 10.1016/j.pop.2015.08.002.

11. Tulay KT, Emrullah T, Aydin A, Ciledag OF. The effect of fibromyalgia syndrome to gravidity, parity and duration of breastfeeding; A prospective study from Turkey. Pak J Med Sci 2016;32(3):545-9. doi: 10.12669/pjms.323.9574.

12. Rodriguez-Pintó I, Agmon-Levin N, Howard A, Shoenfeld Y. Fibromyalgia and cytokines. Immunol Lett 2014;161(2):200-3. doi: 10.1016/j.imlet.2014.01.009.

13. Littlejohn G. Neurogenic neuroinflammation in fibromyalgia and complex regional pain syndrome. Nat Rev Rheumatol 2015;11(11):639-48. doi: 10.1038/nrrheum.2015.100.

14. Mahmut Yener, Ijlal Erturan, Ali Murat Ceyhan, Esra Erkol Inal, Oya
Oylum Kazanoglu, The evaluation of prevalence of fibromyalgia in patients with chronic urticaria. Med Sci Monit 2013;19:757-761. doi:10.12659/MSM.889626

15. Torresani C, Bellafiore S, De Panfilis G. Chronic urticaria is usually associated with fibromyalgia syndrome. Acta Derm Venereol 2009;89(4):389-92. doi: 10.2340/00015555-0653.

16. Wiffen PJ, Derry S, Moore RA, Kalso EA. Carbamazepine for chronic neuropathic pain and fibromyalgia in adults. Cochrane Database Syst Rev 2014;(4):CD005451. doi: 10.1002/14651858.CD005451. pub3.

17. Engin B, Uguz F, Yilmaz E, Ozdemir M, Mevlitoglu I. The levels of depression, anxiety and quality of life in patients with chronic idiopathic urticaria. J Eur Acad Dermatol Venereol 2008;22(1):36-40. doi: 10.1111/j.1468-3083.2007.02324.x.

18. Staubach P, Eckhardt-Henn A, Dechene M, Vonend A, Metz M, Magerl $M$, et al. Quality of life in patients with chronic urticaria is differentially impaired and determined by psychiatric comorbidity. Br J Dermatol 2006;154(2):294-8.

19. O'Donnell BF. Urticaria: impact on quality of life and economic cost. Immunol Allergy Clin North Am. 2014;34(1):89-104. doi: 10.1016/j.iac.2013.09.011.

20. Chinn S, Caldwell W, Gritsenko K. Fibromyalgia Pathogenesis and Treatment Options Update. Curr Pain Headache Rep 2016;20:25.

21. Koca TT, Karaca Acet G, Tanrıkut E, Talu B. Evaluation of sleep disorder and its effect on sexual dysfunction in patients with $\mathrm{Fi}$ bromyalgia syndrome. Turk J Obstet Gynecol 2016;13(4):167-171. doi: 10.4274/tjod.17047.

22. Palagini L, Carmassi C, Conversano C, Gesi C, Bazzichi L, Giacomelli $C$, et al. Transdiagnostic factors across fibromyalgia and mental disorders: sleep disturbances may play a key role. A clinical review. Clin Exp Rheumatol 2016;34:S140-4.

23. Choi DH, Kim HS. Quantitative analysis of nailfold capillary morphology in patients with fibromyalgia. Korean J Intern Med 2015;30(4):531-7. doi: 10.3904/kjim.2015.30.4.531.

24. Morf S, Amann-Vesti B, Forster A, Franzeck UK, Koppensteiner R, Uebelhart D,Sprott $H$. Microcirculation abnormalities in patients with fibromyalgia - measured by capillary microscopy and laser fluxmetry. Arthritis Res Ther 2005;7(2):R209-16. 